\title{
Lowered Serum Dipeptidyl Peptidase IV Activity is Associated with Depressive Symptoms and Cytokine Production in Cancer Patients Receiving Interleukin-2-Based Immunotherapy
}

Michael Maes, M.D., Ph.D., Lucile Capuron, Ph.D., Alain Ravaud, M.D., Norbert Gualde, M.D., Eugene Bosmans, Ph.D., Belinda Egyed, R.T., Robert Dantzer, Ph.D., and Pierre J. Neveu, Ph.D.

There is some evidence that treatment with interleukin-2 (IL-2) and interferon-alpha (IFN $\alpha$ ) frequently induces depressive symptoms and activation of the inflammatory response system (IRS). There is evidence that major depression is accompanied by lowered serum activity of dipeptidyl peptidase IV (DPP IV; EC 3.4.14.5), a membranebound serine protease which catalyses the cleavage of some cytokines and neuro-active peptides and which modulates $T$ cell activation and the production of cytokines, such as IL-2. This study was carried out to examine the effects of immunochemotherapy with IL-2 and IFN $\alpha$, alone and together, in cancer patients on serum DPP IV activity in relation to changes in depressive symptoms and the IRS. The Montgomery and Asberg Rating Scale (MADRS), serum DPP IV activity, and the serum IL-6, and IL-2 receptor (IL-2R) concentrations were measured in 26 patients with metastatic cancers before and three and five days after treatment with IL-2 and IFN $\alpha$, alone or together.
Treatment with IL-2 with or without IFN $\alpha$ significantly suppressed serum DPP IV activity. The MADRS scores were significantly elevated by treatment with IL-2 with or without IFN $\alpha$, but not IFN $\alpha$ alone. The immunochemotherapyinduced decreases in serum DPP IV were significantly and inversely correlated with the increases in the MADRS. Treatment with IL-2 alone or combined with IFN $\alpha$ also elevated serum IL-6 and IL-2R. There were significant and inverse correlations between the immuchemotherapy-induced decreases in serum DPP IV and the elevations in serum IL-6 or IL-2R. In conclusion, treatment with IL-2/IFN $\alpha$ decreases serum DPP IV activity within 3-5 days and the immunochemotherapy-induced decreases in serum DPP IV activity are significantly and inversely related to treatmentinduced increases in severity of depression and signs of activation of the IRS. [Neuropsychopharmacology 24:130140, 2001] (C) 2000 American College of

Neuropsychopharmacology. Published by Elsevier Science Inc.
From the Department of Psychiatry \& Neuropsychology, University of Maastricht, Maastricht, The Netherlands (MM, EB, BE); Department of Psychiatry, Vanderbilt University, Nashville, TX, USA (MM); Clinical Research Center for Mental Health, Antwerp, Belgium (MM); INSERM, U394, Bordeaux, France (LC, RD, PJN); Institut Bergonie, Bordeaux, France (AR, NG); CNRS UMR 5540, Bordeaux, France (AR, NG); and Eurogenetics, Tessenderlo, Belgium (EB).
Address correspondence to: Michael Maes, M.D., Ph.D., Professor of Psychiatry, Chairman of the Department of Psychiatry \& Neuropsychology, University Hospital of Maastricht, Postbus 5800, 6202 AZ Maastricht, The Netherlands.

Received 11 February 2000; revised 4 May 2000; accepted 27 June 2000 
KEY WORDS: Depression; Interleukin-2; Interferon; Dipeptidyl peptidase IV; Cytokines; Immunotherapy

There is now some evidence that major depression is associated with an activation of the inflammatory response system (IRS), as indicated by the following findings: 1) increased serum concentrations of positive acute phase proteins (APPs) and decreased levels of negative APPs; 2) increased numbers of peripheral blood neutrophils, monocytes and activated T cells; 3 ) enhanced production of mono- and T-lymphocytic products, such as neopterin, prostaglandin E2 (PGE2), and elastase; and 4) increased production of proinflammatory cytokines, such as interleukin-1 $\beta$ (IL-1 $\beta$ ), IL-6 and interferon- $\gamma$ (IFN $\gamma$ ) (review: Maes 1999).

Some of the evidence suggesting that cytokines contribute to the genesis of depressive symptoms is based on animal models. Thus, administration of IL-1 to experimental animals may produce behavioral alterations and symptoms similar to those observed in major depression, such as anhedonia, anorexia, weight loss, social withdrawal, psychomotor retardation, anergy, irritability, and sleep disturbances (Yirmiya 1996; Bluthé et al. 1992; Maier and Watkins 1995, 1998; Anisman et al. 1998; Dantzer et al. 1998; Linthorst and Reul 1998). Endotoxin administration to rats decreases the free consumption of saccharin, a model of anhedonia or the inability to experience pleasure (Yirmiya 1996). Sustained elevated serum levels of IL-6 in mice results in a rapid decline in preference for sucrose (Sakic et al. 1997). Administration of IL-1 $\beta$ and tumour necrosis factor-alpha $(\mathrm{TNF} \alpha)$ induce "anxiogenic-like" effects on the elevated plus maze (Connor et al. 1998). In humans, a low dose of IL-6 (0.5 $\mu \mathrm{g} / \mathrm{kg}$ body weight) is associated with increased ratings of fatigue, inactivity and difficulties concentrating (Spath-Schwalbe et al. 1998).

Immunochemotherapy with cytokines, such as IL-2 and IFN $\alpha$, in patients with cancer and hepatitis C, may be accompanied by the appearance of depressive symptoms and full blown major depression. Within the first few days of IL-2 immunochemotherapy, a considerable number of patients report reduced energy, debilitating fatigue, impaired confidence, depressed mood, distress, malaise, poor appetite, weight loss, suicidal ideation, and poor concentration (Denicoff et al. 1987; Baron et al. 1993; Eton et al. 1996; Joffe et al. 1996; Walker et al. 1997). Immunotherapy with IFN $\alpha$ has become standard therapy in (selected) patients with hepatitis and chronic myelogenous leukemia. The psychiatric side effects of IFN $\alpha$ therapy are irritability, crying spells, agitation, anhedonia, anorexia, weight loss, anxiety, social withdrawal, psychomotor retardation, anergy, sleep disturbances and malaise, full blown mood disorders, mostly depression but also mania, suicide, and relapse in drug and alcohol abuse. Moreover, major depression is reported in high frequency as a reason for dose reduction or for stopping immunochemotherapy (Gutterman et al. 1982; Janssen et al. 1994a; Kirkwood et al. 1996; Guilhot et al. 1997; Grob et al, 1998; McHutchison et al. 1998; Davis et al. 1998; Valentine et al. 1998; Van Gool et al. 1999). Treatment of cancer patients with IL-2 increases the plasma concentrations of IL- 6 and the soluble IL-2 receptor (IL-2R), a T cell activation marker, whereas IFN $\alpha$ increases plasma IL-2 (Janssen et al. 1994b; Meffert et al. 1994; Taylor and Grossberg 1998).

Conditions accompanied by activation of the IRS, such as inflammatory and autoimmune disorders (rheumatoid arthritis, autoimmune chronic hepatitis, and systemic lupus erythematosus (Fujita et al. 1978; De Meester 1992; De Meester et al. 1993) and major depression (Maes et al. 1991; Elgun et al. 1999) are characterized by lowered serum activity of dipeptidyl peptidase IV (DPP IV; EC 3.4.14.5). The ectoenzyme DPP IV is a membrane-bound serine protease that catalyses the cleavage of dipeptides from the amino-terminus of oligo-and polypeptides under definite structural conditions (De Meester 1992; De Meester et al. 1999; HopsuHavu and Glenner 1966; Van Hoof et al. 1992). Cytokines, such as tumor necrosis factor-alpha (TNF $\alpha)$ and transforming growth-factor- $\beta$ (TGF- $\beta$ ) may inhibit DPP IV mRNA expression in renal tubular epithelial and carcinoma cells or the expression of DPP IV enzyme activity (Kehlen et al. 1998; Riemann et al. 1995). Therefore, it may be hypothesized that induction of the cytokine network by administration of IL-2 and IFN $\alpha$ may be accompanied by a suppression of serum DPP IV activity which may be related to induction of depressive symptoms.

The aims of the present study were to examine whether: 1) therapy with IL-2 and IFN $\alpha$, alone or together, in patients with metastatic cancers may suppress serum DPP IV activity; and 2) the immunochemotherapy-induced reductions in serum DPP IV activity are inversely related to depressive symptomatology and signs of IRS activation, such as increased serum IL-6 and IL-2R concentrations.

\section{SUBJECTS AND METHODS}

\section{Subjects}

Twenty-six cancer patients participated in the present study. They were studied at the inpatient setting of the Bergonie Institute, Comprehensive Cancer Center, Bordeaux, France between July 1997 and May 1999. The patients were allocated to three treatment groups: 1) Ten patients with metastatic cell carcinoma (seven males/ three females; mean age: $58.2 \pm 11.1$ years) treated with daily subcutaneous IL-2 at a dose of 18 millions of international units (MUI) for five consecutive days; 2) Four men with metastatic cell carcinoma (mean age: $44.0 \pm$ 9.0 years) treated with IL-2 (subcutaneous $18 \mathrm{MUI} / \mathrm{m}^{2}$ per day during five consecutive days) and IFN $\alpha$ (subcu- 
taneous at the dose of 6 MUI on the first, third, and fifth day after starting treatment); and 3) Twelve patients with metastatic cell carcinoma or melanoma (six males / six females; mean age $=48.6 \pm 12.0$ years) treated with subcutaneous (s.c.) IFN $\alpha$ or intravenous (i.v.) injections of IFN $\alpha$. IFN $\alpha$ was administered s.c. on days 1,3 , and 5 in daily doses of $18 \mathrm{MUI}$ to three subjects (one male/ two females) or was injected i.v. in daily doses of 20 $\mathrm{MUI} / \mathrm{m}^{2}$ for five consecutive days in nine subjects (five males/four females). These two latter groups treated with IFN $\alpha$, i.v. or s.c., were combined, because there were no significant differences in the MADRS, DPP IV and cytokine responses between both groups. All patients gave written informed consent after complete description of the study. This study was approved by the local committee for the protection of patients in biomedical research (CCPPRB).

\section{Methods}

Blood samples for the assays of serum DPP IV activity and serum IL-6 and IL-2R concentrations were collected just before starting treatment (baseline) and three and five days later. Blood was collected around 9.00 a.m. ( $\pm 60 \mathrm{~min}$ ) before the administration of IL-2 and/or IFN $\alpha$. Sera were stored at $-70^{\circ} \mathrm{C}$ until thawed for assay. The Montgomery and Asberg Depression Rating Scale (MADRS) was used to assess the intensity of depressive symptoms (Montgomery and Asberg 1979). The MADRS was scored the same day as blood was collected, i.e., in baseline conditions, and three and five days later.

Serum DPP IV was determined by means of a colorimetric method using the chromogenic substrate glycylL-proline-p-nitroanilide tosylate (Gly-Pro-p-NA) (Nagatsu et al. 1976). The method was adapted for direct continuous measurement on the centrifugal analyzer Cobas Bio (Roche Diagnostics, Germany). The sensitivity of the assay was $3.0 \mathrm{U} / \mathrm{L}$. The conversion factors to transform the units (U) employed in this study to the SI units are: $1 \mathrm{U} / \mathrm{L}$ corresponds to $16.67 \times 10^{-9} \mathrm{~kat} / \mathrm{L}$, and $1 \times$ $10^{-9} \mathrm{~kat} / \mathrm{L}$ corresponds to $0.06 \mathrm{U} / \mathrm{L}$. The sera of all subjects were assayed on the same day and in one and the same run by the same operator. The analytical imprecision (i.e., the coefficient of variation, expressed as a percentage, $\mathrm{CV} \%$ ) of our DPP IV assay was $\mathrm{CV}=2.2 \%$ (Maes et al. 1994). Serum IL-6 was measured by a quantitative enzyme-linked immunosorbent assay (ELISA) (Eurogenetics, Tessenderlo, Belgium) based on appropriate and validated sets of monoclonal antibodies. Serum IL-2R was measured by an EIA (Eurogenetics, Tessenderlo, Belgium). All serum specimens for IL-6 and IL$2 \mathrm{R}$ were assayed in a single run with a single lot number of reagents and consumables employed by a single operator. The intra-assay coefficient of variation for IL-6 was $<8.0 \%$ and for IL-2R it was $2.0 \%$. The operators were blind to the treatment schedules of the patients.

\section{Statistics}

Group mean differences were checked by means of analyses of variance (ANOVA). Repeated measure (RM) design ANOVAs were employed to examine the within-subject variability with the baseline and posttreatment values (Days 3 and 5) as time factor, the between-subject variability with the three treatment groups as factors, and two-way interactions between time $\times$ treatment groups. RM design ANOVAs were carried out using the regression method in order to control for the non-balanced number of subjects in the treatment groups. The results of RM design ANOVAs were corrected for sphericity. Tests on simple effects were carried out in order to examine significant main effects or significant interaction patterns (Howell 1982). The results were double-checked with the non-parametric Friedman test. Comparisons among treatment means and diagnosis were carried out with the Dunn test (Howell 1982). Relationships between variables were assessed by means of Pearson's product-moment and the point-biserial correlation coefficients. In order to examine the relationships between the IL-2/IFN $\alpha$ induced changes in the MADRS, serum DPP IV and IL-6 or IL-2R, we computed the correlations between the residualized values with the endpoint (Day 3 or 5) values as dependent variable and the baseline values as independent variable. The variables were processed in transformation, where appropriate, i.e., DPP IV and IL-2R in square root transformation and IL-6 in Box-Cox transformation.

\section{RESULTS}

Figure 1 shows the MADRS scores and serum DPP IV activity in baseline conditions and three and five days after administration of IL-2 and/or IFN $\alpha$. RM design ANOVA performed on the MADRS values showed a significant effect of time ( $\mathrm{F}=9.7, \mathrm{df}=2 / 40, p=.0006)$ and a trend toward a significant time $\times$ group interaction $(\mathrm{F}=2.3$, $\mathrm{df}=4 / 40, p=.07)$. Analyses on simple effects showed significant effects of time in subjects treated with IL-2 + $\operatorname{IFN} \alpha(\mathrm{F}=4.7, \mathrm{df}=2 / 44, p=.01), \mathrm{IL}-2(\mathrm{~F}=11.1, \mathrm{df}=2$ / $44, p=.0003)$, but not in those treated with IFN $\alpha$ alone $(\mathrm{F}=0.4, \mathrm{df}=2 / 44, p=.7)$. In subjects treated with IL-2 and IL-2 + IFN $\alpha$, but not in those treated with IFN $\alpha$ alone, pairwise comparisons showed significantly higher MADRS values three and five days after starting treatment than in baseline conditions $(p<.05)$.

RM design ANOVA performed on the DPP IV data showed a significant effect of time $(\mathrm{F}=8.6, \mathrm{df}=2 / 37, p=$ $.001)$ and a significant time $\times$ group interaction $(\mathrm{F}=$ $5.1, \mathrm{df}=3 / 37, p=.005)$. Analyses of simple effects showed significant effects of time in subjects treated with IL-2 + IFN $\alpha(\mathrm{F}=8.5, \mathrm{df}=2 / 46, p=.001)$ and IL-2 

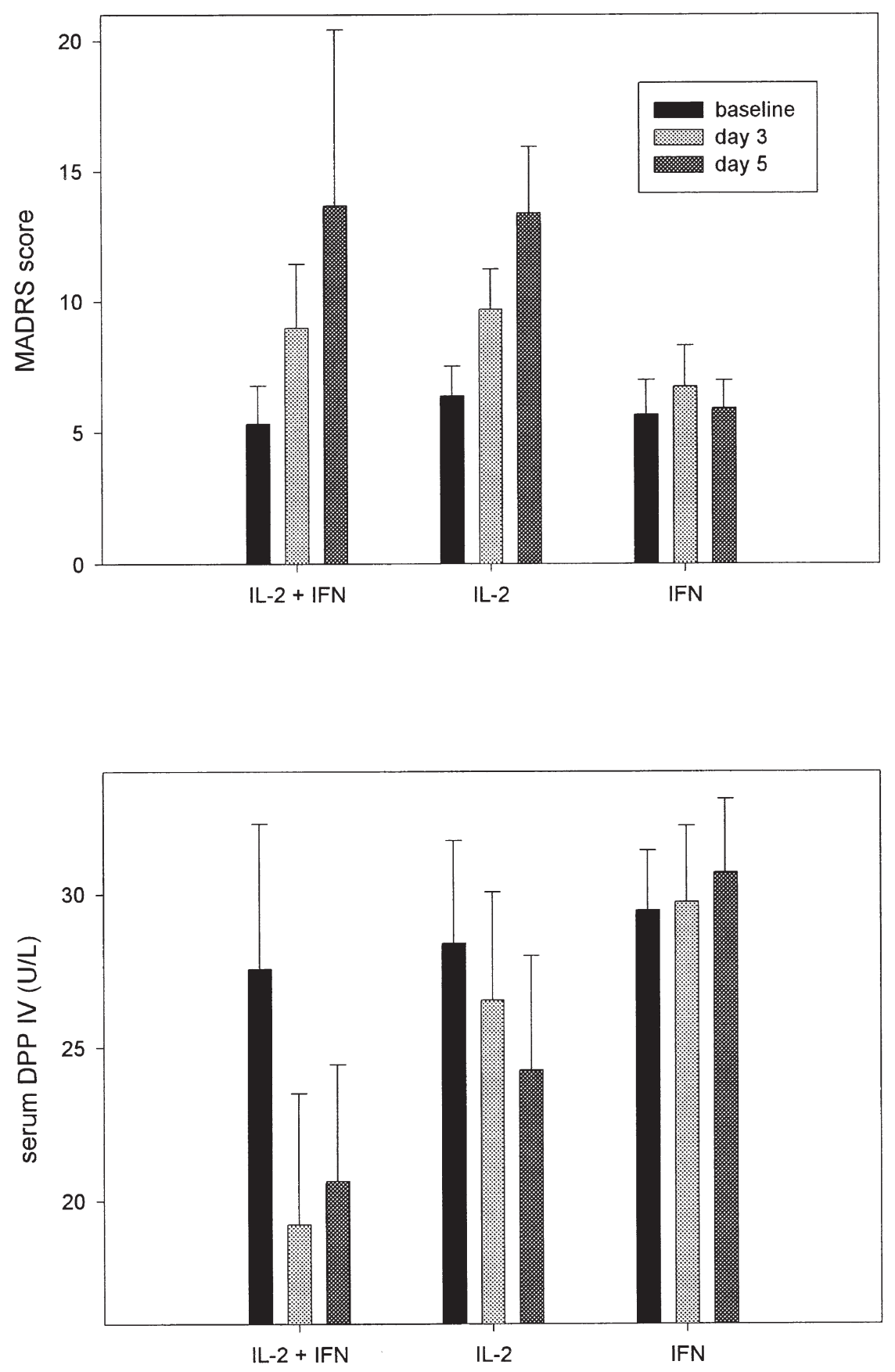

Figure 1. Bar chart (mean \pm SEM) showing the scores on the Montgomery and Asberg Rating Scale (MADRS) and serum activity of dipeptidyl peptidase IV (DPP IV; EC 3.4.14.5) in 26 patients with metastatic cancers before (baseline) and three (Day 3) and five days (Day 5) after treatment with interleukin-2 (IL-2), IL-2 and interferon- $\alpha$ (IL-2 + IFN), and IFN alone.
$(\mathrm{F}=5.3, \mathrm{df}=2 / 46, p=.008)$, but not in those treated with IFN $\alpha$ alone $(\mathrm{F}=0.4, \mathrm{df}=2 / 46, p=.7)$. In subjects treated with IL-2 + IFN $\alpha$, but not in those treated with IFN $\alpha$ alone, pairwise comparisons showed significantly lower DPP IV values three and five days after starting treatment than in baseline conditions $(p<.05)$.

In subjects treated with IL-2 alone, pairwise comparisons showed significantly lower DPP IV values five days after starting treatment than in baseline conditions $(p<.05)$. In all subjects combined, Dunn tests showed significantly lower serum DPP IV activity three $(\mathrm{t}=$
2.38, $p=.02)$ and five $(\mathrm{t}=2.70, p=.009)$ days after treatment than in baseline conditions. Also, using the non-parametric Friedman test, we found that there were significant differences in DPP IV between the three conditions (i.e., baseline, Day 3 and Day 5) in patients treated with IL-2 with or without IFN $\alpha(p=$ $.0006, n=14)$, with IL-2 alone ( $p=.007, n=10)$, with IL-2 $+\operatorname{IFN} \alpha(p=.04, n=4)$, but not in those treated with IFN $\alpha$ alone ( $p=.5, n=12$ ). There was a significant and positive correlation between the residualized (Day 5/baseline) MADRS scores and serum DPP IV ( $\mathrm{r}=$ 
$-0.49, p=.01)$, suggesting that the changes in the MADRS and serum DPP IV from baseline to 5 days later are significantly and positively correlated.

Although the effects of IL-2/IFN $\alpha$ on the serum concentrations of cytokines, such as IL-6 and IL-8, and cytokine receptors, such as the IL-2R, have been published elsewhere (Capuron et al., submitted), we report here on the associations between the IL-2/IFN $\alpha$ induced-changes in DPP IV and the treatment-induced changes in serum IL-6 and IL-2R, since the latter are sensitive markers of in vivo IRS activation. Figure 2 shows the serum IL- 6 and IL-2R responses to IL-2 and
IFN $\alpha$ in the cancer patients. RM design ANOVA performed on the serum IL- 6 values showed a significant effect of time ( $\left.\mathrm{F}=15.5, \mathrm{df}=2 / 45, p<10^{-4}\right)$ and a trend toward a significant time $\times$ group interaction $(\mathrm{F}=2.4$, $\mathrm{df}=4 / 45, p=.06$ ). Analyses on simple effects showed significant time effects in patients treated with IL-2 + $\operatorname{IFN} \alpha(\mathrm{F}=7.6, \mathrm{df}=2 / 46, p=.002)$ and IL-2 ( $\mathrm{F}=10.1$, $\mathrm{df}=2 / 46, p=.0004)$, but not in those with IFN $\alpha$ alone $(\mathrm{F}=1.5, \mathrm{df}=2 / 46, p=.2)$.

In subjects treated with IL-2 + IFN $\alpha$ and IL-2 alone, but not in those treated with IFN $\alpha$ alone, pairwise comparisons showed significantly higher serum IL-6 three
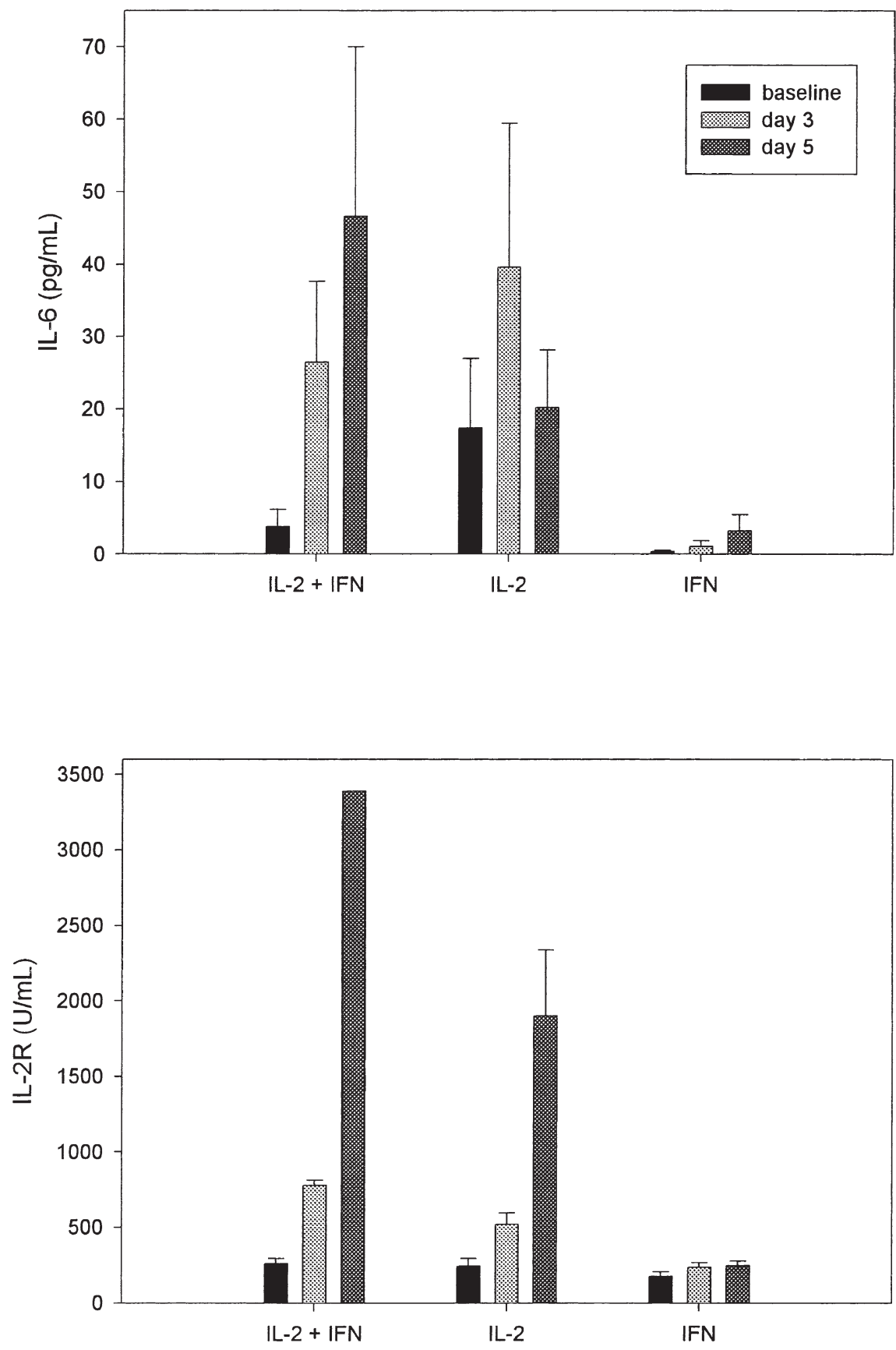

Figure 2. Bar chart (mean \pm SEM) showing serum interleukin-6 (IL-6) and IL-2 receptor (IL-2R) in 26 patients with metastatic cancers before (baseline) and three (Day 3) and five days (Day 5) after treatment with interleukin-2 (IL-2), IL-2 and interferon- $\alpha$ (IL-2 + IFN), and IFN alone. 
and five days after starting treatment than in baseline conditions $(p<.05)$. In all patients combined, Dunn's test showed significantly higher serum IL-6 three $(\mathrm{t}=$ $4.26, p=.0002)$ and five $(\mathrm{t}=4.69, p=.0001)$ days after treatment than before. There were significant correlations between the residualized DPP IV data (Day 5/ baseline) and the residualized IL-6 values three (Day 3/ baseline; $\mathrm{r}=-0.47, p=.01$ ) and five (Day 5/baseline; $\mathrm{r}=$ $-0.42, p=.03$ ) days after starting treatment. Figure 3 shows the correlation between the residualized DPP IV data (Day 5/baseline) and the residualized IL-6 values three days after starting treatment, suggesting that the changes in DPP IV from baseline to five days later may be predicted (statistically) by the changes in serum IL-6 from baseline to three days later.

Figure 2 shows the effects of immunotherapy on serum IL-2R. RM design ANOVA performed on the IL-2R data showed a significant effect of time $(\mathrm{F}=3.5, \mathrm{df}=$
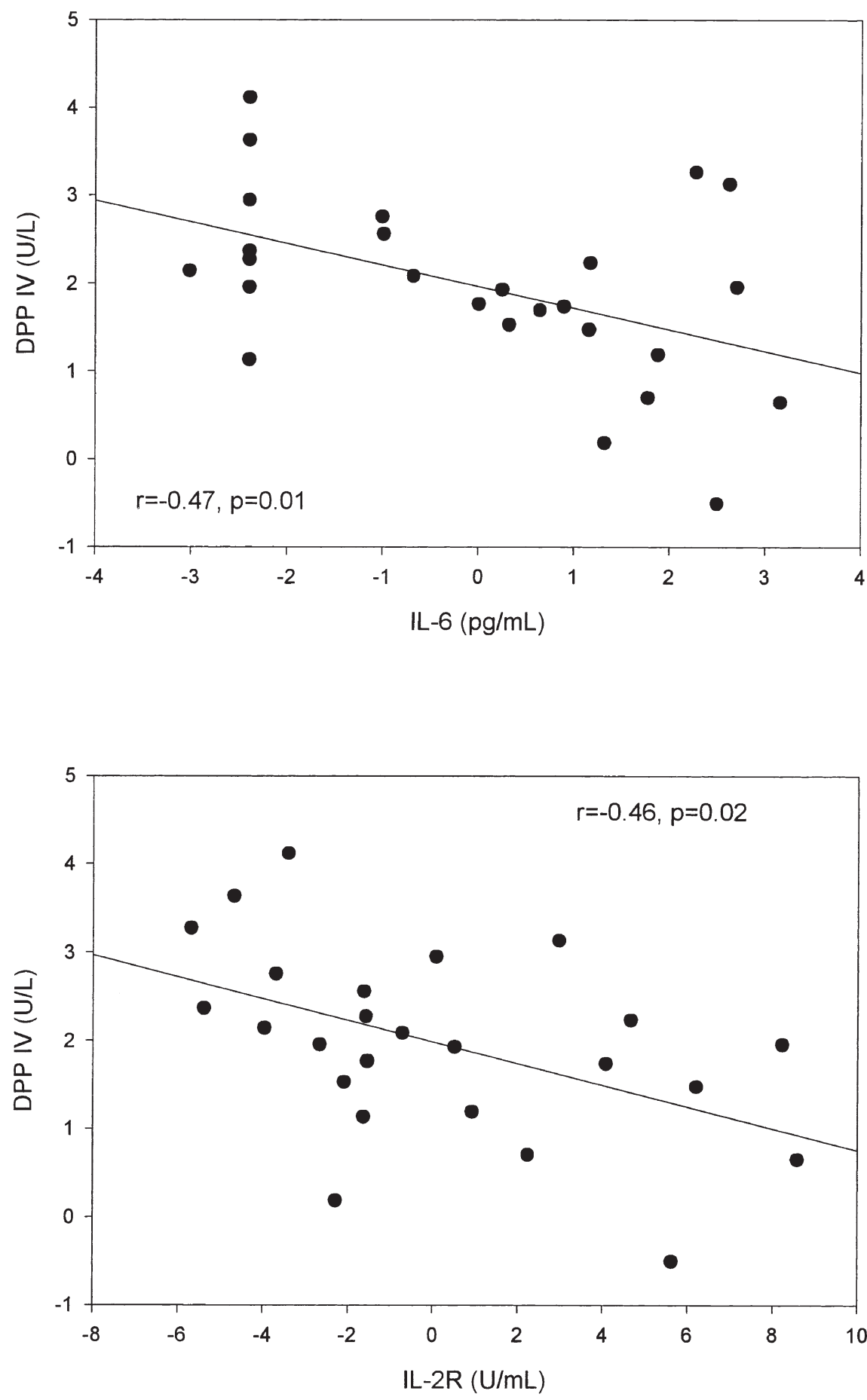

Figure 3. Regressions of the residualized DPP IV data (Day 5/baseline; in Box-Cox transformation) on the residualized interleukin-6 (IL-6) and IL-2 receptor (IL-2R) values (Day 3/ baseline), suggesting that the changes in DPP IV from baseline to five days later may be predicted by the changes in serum IL-6 and IL-2R from baseline to three days later. 
$1 / 22, p<10^{-4}$ ) and a significant time $\times$ group interaction $\left(\mathrm{F}=17.7, \mathrm{df}=2 / 22, p<10^{-4}\right)$. Analyses on simple effects showed significant effects of time in subjects treated with IL-2 + IFN $\alpha\left(\mathrm{F}=36.5, \mathrm{df}=2 / 44, p<10^{-4}\right)$ and IL-2 $\left(\mathrm{F}=34.0, \mathrm{df}=2 / 44, p<10^{-4}\right)$, but not in those treated with IFN $\alpha$ alone $(\mathrm{F}=0.07 \mathrm{df}=2 / 44, p=.9)$. In subjects treated with IL- $2+$ IFN $\alpha$, and IL-2 and IFN $\alpha$ alone, pairwise comparisons showed significantly higher serum IL-2R values three and five days after starting treatment than in baseline conditions $(p<.05)$. In all subjects combined, Dunn's test showed significantly higher serum IL-2R values five days after treatment $\left(\mathrm{t}=7.89, p<10^{-4}\right)$ than before and significantly higher serum IL-2R values five days after treatment than after three days $\left(\mathrm{t}=6.39, p<10^{-4}\right)$.

There were significant inverse correlations between the residualized serum DPP IV values (day 5 / baseline) and the residualized IL-2R values, three $(\mathrm{r}=-0.46, p=$ $.02)$ and five $(r=-0.42, p=0.03)$ days after starting treatment. Figure 3 shows the correlation between the residualized DPP IV data (day 5/ baseline) and the residualized IL-2R values three days after starting treatment, suggesting that the changes in DPP IV from baseline to 5 days later may be predicted (statistically) by the changes in serum IL-2R from baseline to three days later.

There were no significant differences in age $(\mathrm{F}=2.8$, $\mathrm{df}=2 / 25, p=.08)$ and in the men/women ratio $\left(\chi^{2}=\right.$ $3.4 \mathrm{df}=2, p=.2)$ between the study groups. There were no significant correlations between age and the residualized MADRS ( $\mathrm{r}=-0.02, p=.9)$, DPP IV $(\mathrm{r}=-0.19, p=$ .6), IL-6 ( $\mathrm{r}=-0.05, p=.8)$, and IL-2R $(\mathrm{r}=-0.05, p=.8)$ values. There were no significant point-biserial correlations between gender and the residualized MADRS $(\mathrm{r}=$ $-0.08 ; p=.7)$, DPP IV $(\mathrm{r}=0.25, p=.2)$, IL-6 $(\mathrm{r}=0.14, p=$ $.5)$, and IL-2R $(\mathrm{r}=-0.13, p=.5)$ values.

\section{DISCUSSION}

The major findings of this study are that treatment with IL-2 (with or without IFN $\alpha$ ), but not IFN $\alpha$ alone, significantly reduced serum DPP IV activity, and that the therapy-induced reductions in serum DPP IV are significantly and inversely related to therapy-induced increases in the MADRS score and in serum IL-6 and IL-2R concentrations.

To the best of our knowledge, this is a first study reporting that treatment of cancer patients with IL-2 and IL-2 + IFN $\alpha$ significantly suppresses serum DPP IV activity. Treatment with IL-2 + IFN $\alpha$ resulted in a faster suppression of DPP IV activity (obtained three days after starting treatment) than therapy with IL-2 alone (obtained five days after starting treatment). These findings could perhaps be ascribed to a potentiation of the effects of IL-2 by IFN $\alpha$. The mechanisms whereby se- rum DPP IV activity is lowered has remained elusive. The origin of serum DPP IV is, in part, determined by peripheral tissues, such as T lymphocytes, the liver, endothelial cells and platelets (Kasahara et al. 1984; review: Scharpé et al. 1990). There is a known relationship between DPP IV and the ligand CD26 which has been localized on T cells. CD26, a $110 \mathrm{kDa}$ T cell surface glycoprotein, exhibits DPP IV enzyme activity and has been shown to play a crucial role in $\mathrm{T}$ cell activation and production of cytokines, such as IL-2 and IFN $\gamma$ (Ansorge and Schon 1987; Duke-Cohan et al. 1995; Reinhold et al. 1996; Schon et al. 1989; Tanaka et al. 1994; Schmitz et al. 1996; De Meester et al. 1999).

In $\mathrm{HIV}^{+}$patients, IL-2 immunochemotherapy results in a significant increase in the number of $\mathrm{CD} 26^{+} \mathrm{T}$ cells (De Paoli et al. 1997). On human natural killer cells, CD26 expression is inducible by IL-2 (Yamabe et al. 1997). On the T cell surface, the expression of the CD26 molecule is increased together with that of other activation markers, e.g. HLA-DR (Barton et al. 1990; Iwaki-Egawa et al. 1995; Mattern et al. 1991; Scholz et al. 1985). The suppressant effects of IL-2 immunochemotherapy on serum DPP IV activity may be attributed to at least three different mechanisms: 1) Diminished shedding of DPP IV from IL-2 activated T lymphocytes; 2) Differences in the effects of IL-2 on CD26 expression in normal volunteers versus cancer patients. For example, when peripheral blood T lymphocytes of oral cancer patients are cultured in the presence of IL-2, the expression of CD26 on the membranes is significantly lower in the patients than in healthy controls (Uematsu et al. 1998); and 3) Cytokines, such as TNF $\alpha$ and TGF $\beta$, which secretion may be enhanced by IL-2, may reduce DPP IV expression. Thus, Kehlen et al. (1998) reported that TNF $\alpha$ and TGF $\beta$ decrease DPP IV/CD26 mRNA in renal tubular epithelial cells and renal cell carcinoma cells in culture. TGF $\beta$ inhibits the expression and enzyme activity of DPP IV (Riemann et al. 1995). IFN $\alpha$, on the other hand, may increase DPP IV/CD26 mRNA expression in the same cultures (Kehlen et al. 1998).

A second major finding of this study is the significant and inverse relationship between the treatmentinduced increases in serum IL- 6 and IL-2R and decreases in serum DPP IV. The findings that immunochemotherapy increases the serum concentrations of IL- 6 and IL-2R suggests that IL-2 with or without IFN $\alpha$ induces a potent stimulation of the cytokine network, suggesting $\mathrm{T}$ cell (increased serum IL-2R and IL-6) and monocytic (increased serum IL-6) activation (Cavaillon 1996). These results are in agreement with previous studies reporting that IL-2 with or without IFN $\alpha$ induces the production of secondary cytokines, such as IL-6 (see Introduction) and the IL-2R (Cavaillon 1996). The results that the changes in serum DPP IV are inversely correlated to serum IL- 6 and IL-2R suggest that 
serum DPP IV activity is sensitive to graded differences in IRS activation. These findings are in accordance with previous studies showing that lower serum DPP IV activity accompanies inflammatory disorders, such as rheumatoid arthritis, colitis ulcerosa, autoimmune chronic hepatitis, and systemic lupus erythematosus (Fujita et al. 1978; De Meester 1992; De Meester et al. 1993).

The third major finding of this study is that there was a significant inverse relationship between therapyinduced increases in the MADRS score and decreases in serum DPP IV. Our findings that IL-2 with or without IFN $\alpha$ significantly increases the MADRS is in accordance with a number of studies that cancer patients treated with IL-2 (see Introduction) or IL-2 + IFN $\alpha$ (Schnittman et al. 1994) develop early depressive symptoms. The differences in the MADRS responses to IL-2 with or without IFN $\alpha$ versus IFN $\alpha$ alone may be explained by findings that depressive symptoms develop within some days after starting IL-2 immunochemotherapy, whereas depressive symptoms appear later during IFN $\alpha$ immunochemotherapy (Capuron and Ravaud 1999). In the cancer patients treated with IL-2 with or without IFN $\alpha$ we found that the scores on all MADRS items, except reduced sleep, (i.e., apparent and reported sadness; inner tension; reduced appetite; concentration difficulties; lassitude; inability to feel; pessimistic and suicidal thoughts) significantly increased from baseline to five days later (Capuron et al. 2000). These findings suggest that immunotherapy with IL-2 with or without IFN $\alpha$ not only induces the vegetative symptoms of depression but also core depressive symptoms. In this respect, it is thought that IL-2 and/or IFN $\alpha$ and/or their secondary induced cytokines, such as IL-6, may exert their depressogenic activities through their effects on brain serotonergic and catecholaminergic activity and on the corticotropin-releasing hormone-cortisol axis (review: Maes 1999; Yirmiya 1997).

The findings that the therapy-induced changes in serum DPP IV activity are inversely related to the MADRS score extend previous results that lower serum DPP IV activity occurs in major depression and that there is a significant inverse correlation between serum DPP IV activity and severity of depression in that illness (Maes et al. 1991, 1994, 1997; Elgun et al. 1999). It is interesting to note that in depression, lowered serum DPP IV activity is related to signs of IRS activation, such as decreases in serum concentrations of negative acute phase reactants, e.g., serum zinc and transferrin (Maes et al. 1997). Even if other factors, such as stimulation of the cytokine network, initiate the genesis of depression in patients treated with IL-2 (and IFN $\alpha$ ), lowered DPP IV may contribute to the persistence of depression. Indeed, the suppressed activity of DPP IV following immunotherapy may have psychoneuroimmune consequences, since some cytokines, chemokines and neuro-active peptides are potential substrates of DPP IV, e.g., IL-1 $\beta$, IL-6, substance $P$, growth hormone releasing hormone $(\mathrm{GHRH})$, neuropeptide $Y$, and peptide YY (Conlon and Sheehan 1983; Frohman et al. 1989; Mentlein et al. 1993; Zukowska-Grojec 1997; Van Hoof et al. 1995). Thus, a decreased proteolysis of pro-inflammatory cytokines, e.g., IL-1 $\beta$ and IL-6, and neuroactive peptides, such as substance $\mathrm{P}$, may be accompanied by an increased inflammatory capacity and, thus, aggravation of immunotherapy-induced depression.

There are now several reports indicating a role for DPP IV in tumor cell metastasis and in cellular trafficking through the extracellular matrix (Ruiz et al. 1998). For example, DPP IV expressed on rat lung capillary endothelia is an adhesion receptor for breast cancer cells (Cheng et al. 1998). Membrane-associated proteases, such as DPP IV, allow metastasing cancer cells to invade the extracellular matrix (Chen 1996). Therefore, it is thought that the inhibition of DPP IV may be a new approach to suppress cancer spread (Riemann et al. 1995). Consequently, it is tempting to hypothesize that part of the efficacy of IL-2 in the treatment of metastatic cancers may be related to its suppressant effect on DPP IV activity and, thus, on the cellular trafficking through the extracellular matrix and thus metastatic spread.

A first limitation of the present study is that the study is limited to observations approximately one week after therapy. Another limitation is that only one rating scale for depression was used. A third limitation of the present study is the small sample size. Directions for future research include the assessment of DPP IV activity in relation to adenosine deaminase and the cytokine network following repeated administration of IL-2 and/or IFN $\alpha$ for longer periods of time. Our laboratory examines now the long-term effects of treatment with IFN $\alpha$ on serum DPP IV activity and on the cytokine network in relation to a number of rating scales, assessing depression and anxiety.

\section{REFERENCES}

Anisman H, Kokkinidis L, Borowski T, Merali Z (1998): Differential effects of interleukin (IL)-1beta, IL-2 and IL-6 on responding for rewarding lateral hypothalamic stimulation. Brain Res 779:177-187

Ansorge S, Schon E (1987): Dipeptidyl peptidase IV (DP IV), a functional marker of the T lymphocyte system. Acta Histochem 82:41-46

Baron DA, Hardie T, Baron SH (1993): Possible association of interleukin-2 treatment with depression and suicide. J Am Osteopath Assoc 93:799-800

Barton RW, Prendergast J, Kennedy CA (1990): Binding of the $T$ cell activation monoclonal antibody TA1 to dipeptidyl peptidase IV. J Leukoc Biol 48:291-296

Bluthé RM, Crestani F, Kelley KW, Dantzer R (1992): Mecha- 
nisms of the behavioral effects of interleukin 1. Ann NY Acad Sci 650:268-275

Capuron L, Ravaud A (1999): Prediction of the depressive effects of interferon alfa therapy by the patient's initial affective state. N Engl J Med 340:1370

Capuron L, Ravaud A, Dantzer R (2000): Early depressive symptoms in cancer patients receiving interleukin-2 and/or interferon alpha therapy. J Clin Oncol in press

Cavaillon J-M (1996): Les Cytokines. Paris, Masson

Chen WT (1996): Proteases associated with invadopodia, and their role in degradation of extracellular matrix. Enzyme Prot 49:59-71

Cheng HC, Abdel-Ghany M, Elble RC, Pauli BU (1998): Lung endothelial dipeptidyl peptidase IV promotes adhesion and metastasis of rat breast cancer cells via tumor cell surface-associated fibronectin. J Biol Chem 273:24207-24215

Conlon JM, Sheehan L (1983): Conversion of substance P to C-terminal fragments in human plasma. Regul Pept 7:335-345

Connor TJ, Song C, Leonard BE, Merali Z, Anisman H (1998): An assessment of the effects of central interleukin-1beta, $-2,-6$, and tumor necrosis factor-alpha administration on some behavioural, neurochemical, endocrine and immune parameters in the rat. Neuroscience 84:923-933

Dantzer R, Bluthé RM, Laye S, Bret-Dibat JL, Parnet P, Kelley KW (1998): Cytokines and sickness behavior. Ann NY Acad Sci 840:586-590

Davis GL, Esteban-Mur R, Rustgi V, Hoefs J, Gordon SC, Trepo C, Shiffman ML, Zeuzem S, Craxi A, Ling MH, Albrecht J (1998): Interferon alfa-2b alone or in combination with ribavirin for the treatment of relapse of chronic hepatitis C. International Hepatitis Interventional Therapy Group. N Engl J Med 339:1493-1499

De Meester IAJ (1992): Characterization of human lymphocytic dipeptidyl peptidase IV and its identification as the activation antigen CD 26. Ph.D. Thesis, Antwerp

De Meester IAJ, Mertens AV, De Clerck LS, Scharpé S, Bridts CH, Stevens WJ (1993): Correlations between dipeptidyl peptidase IV and disease activity of rheumatoid arthritis (RA). J Allergy Clin Immunol 91:228-232

De Meester IAJ, Korom S, Van Damme J, Scharpe S (1999): CD26, let it cut or cut it down. Immunol Today 20:367-375

Denicoff KD, Rubinow DR, Papa MZ, Simpson C, Seipp CA, Lotze MT, Chang AE, Rosenstein D, Rosenberg SA (1987): The neuropsychiatric effects of treatment with interleukin-2 and lymphokine-activated killer cells. Ann Intern Med 107:293-300

De Paoli P, Zanussi S, Simonelli C, Bortolin MT, D'Andrea M, Crepaldi C, Talamini R, Comar M, Giacca M, Tirelli U (1997): Effects of subcutaneous interleukin-2 therapy on CD4 subsets and in vitro cytokine production in HIV+ subjects. J Clin Invest 100:2737-2743

Duke-Cohan JS, Morimoto C, Rocker JA, Schlossman SF (1995): A novel form of dipeptidylpeptidase IV found in human serum: Isolation, characterization, and comparison with T lymphocyte membrane dipeptidylpeptidase IV (CD26). J Biol Chem 270:14107-14114

Elgun S, Keskinege A, Kumbasar H (1999): Dipeptidyl pepti- dase IV and adenosine deaminase activity. Decrease in depression. Psychoneuroendocrinology 24:823-832

Eton O, Talpaz M, Lee KH, Rothberg JM, Brell JM, Benjamin RS (1996): Phase II trial of recombinant human interleukin-2 and interferon-alpha-2a: implications for the treatment of patients with metastatic melanoma. Cancer 77:893-899

Frohman L, Downs T, Heimer E, Felix A (1989): Dipeptidyl peptidase IV and trypsin-like enzymatic degradation of human growth hormone releasing hormone in plasma. J Clin Invest 83:1533-1540

Fujita K, Hirano M, Ochiai J, Funabashi M, Nagatsu I, Nagatsu T, Sakakibara S (1978): Serum glycylproline p-nitroanilidase activity in rheumatoid arthritis and systemic lupus erythematosus. Clin Chem 88:15-20

Grob JJ, Dreno B, de la Salmoniere P, Delaunay M, Cupissol D, Guillot B, Souteyrand P, Sassolas B, Cesarini JP, Lionnet S, Lok C, Chastang C, Bonerandi JJ (1998): Randomised trial of interferon alpha-2a as adjuvant therapy in resected primary melanoma thicker than $1.5 \mathrm{~mm}$ without clinically detectable node metastases. French Cooperative Group on Melanoma. Lancet 351:1905-1910

Guilhot F, Chastang C, Michallet M, Guerci A, Harousseau JL, Maloisel F, Bouabdallah R, Guyotat D, Cheron N, Nicolini F, Abgrall JF, Tanzer J (1997): Interferon alfa-2b combined with cytarabine versus interferon alone in chronic myelogenous leukemia. French Chronic Myeloid Leukemia Study Group. N Engl J Med 337:223-229

Gutterman JU, Fine S, Quesada J, Horning SJ, Levine JF, Alexanian R, Bernhardt L, Kramer M, Spiegel H, Colburn W, Trown P, Merigan T, Dziewanowski Z (1982): Recombinant leukocyte A interferon: Pharmacokinetics, single-dose tolerance, and biologic effects in cancer patients. Ann Intern Med 96:549-556

Hopsu-Havu VK, Glenner GG (1966): A new dipeptide naphthylamidase hydrolyzing glycyl-propyl-á-naphthylamide. Histochemistry 7:197-201

Howell DC (1982): In Statistical Methods for Psychology. Boston, Duxbury Press

Iwaki-Egawa S, Watanabe Y, Fujimoto Y (1995): Is CD26/ dipeptidyl peptidase IV a really important molecule in $\mathrm{T}$ cell activation of a certain rat strain. Immunobiology 194:429-442

Janssen HL, Brouwer JT, van der Mast RC, Schalm SW (1994a): Suicide associated with alfa-interferon therapy for chronic viral hepatitis. J Hepatol 21:241-243

Janssen RA, Mulder NH, The TH, de Leij L (1994b): The immunobiological effects of interleukin-2 in vivo. Cancer Immunol Immunother 39:207-216

Joffe JK, Banks RE, Forbes MA, Hallam S, Jenkins A, Patel PM, Hall GD, Velikova G, Adams J, Crossley A, Johnson PW, Whicher JT, Selby PJ (1996): A phase II study of interferon-alpha, interleukin-2 and 5-fluorouracil in advanced renal carcinoma: Clinical data and laboratory evidence of protease activation. Br J Urol 77:638-649

Kasahara Y, Leroux-Roels G, Nakamura R, Chisari F (1984): Glycylprolyl-diaminopeptidase in human leukocytes: Selective occurrence in T lymphocytes and influence on the total serum enzyme activity. Clin Chim Acta 139: 295-302

Kehlen A, Gohring B, Langner J, Riemann D (1998): Regula- 
tion of the expression of aminopeptidase A, aminopeptidase N/CD13 and dipeptidylpeptidase IV/CD 26 in renal carcinoma cells and renal tubular epithelial cells by cytokines and cAMP-increasing mediators. Clin Exp Immunol 111:435-441

Kirkwood JM, Strawderman MH, Ernstoff MS, Smith TJ, Borden EC, Blum RH (1996): Interferon alfa-2b adjuvant therapy of high-risk resected cutaneous melanoma: The Eastern Cooperative Oncology Group Trial EST 1684. J Clin Oncol 14:7-17

Linthorst AC, Reul JM (1998): Brain neurotransmission during peripheral inflammation. Ann NY Acad Sci 840:139-152

Maes M (1999): Major depression and activation of the inflammatory response system. Adv Exp Med Biology 461:25-46

Maes M, De Meester I, Vanhoof G, Scharpé S, Bosmans E, Vandervorst C, Verkerk R, Minner B, Suy E, Raus J (1991): Decreased serum dipeptidyl peptidase IV activity in major depression. Biol Psychiatry 30:577-586

Maes M, Scharpé S, De Meester I, Goossens P, Wauters A, Neels H, Verkerk R, De Meyer F, D'Hondt P, Peeters D, Schotte C, Cosyns P (1994): Components of biological variation in plasma prolyl endopeptidase and dipeptidyl peptidase activity in healthy man. Clin Chem 40: 1686-1691

Maes M, De Meester I, Verkerk R, Demedts P, Wauters A, Vanhoof G, Vandoolaeghe E, Neels H, Scharpe S (1997): Dipeptidyl peptidase serum activity in treatment resistant depression: Relationships with immune-inflammatory markers. Psychoneuroendocrinology 22:65-78

Maier SF, Watkins LR (1995): Intracerebroventricular interleukin-1 receptor antagonist blocks the enhancement of fear conditioning and interference with escape produced by inescapable shock. Brain Res 695:279-282

Maier SF, Watkins LR (1998): Cytokines for psychologists: implications of bidirectional immune-to-brain communication for understanding behavior, mood, and cognition. Psychol Rev 105:83-107

Mattern T, Scholz W, Feller AC, Flad HD, Ulmer AJ (1991): Expression of CD26 (Dipeptidyl peptidase IV) on resting and activated human lymphocytes-T. Scand J Immunol 33:737-748

Meffert M, Hanninen EL, Menzel T, Schomburg A, Duensing S, Dallmann I, Grosse J, Vocke S, Buer J, Deckert M, et al. (1994): In vivo time and dose dependency of interleukin6 secretion in response to low-dose subcutaneous recombinant interleukin-2. Cancer Biother 9:307-316

McHutchison JG, Gordon SC, Schiff ER, Shiffman ML, Lee WM, Rustgi VK, Goodman ZD, Ling MH, Cort S, Albrecht JK (1998): Interferon alfa-2b alone or in combination with ribavirin as initial treatment for chronic hepatitis C. Hepatitis Interventional Therapy Group. N Engl J Med 339:1485-1492

Mentlein R, Dahms P, Grandt D, Kruger R (1993): Proteolytic processing of neuropeptide $\mathrm{Y}$ and peptide $\mathrm{YY}$ by dipeptidyl peptidase IV. Regul Pept 49:133-144

Montgomery SA, Asberg A (1979): A new depression scale designed to be sensitive to change. Br J Psychiatry 134:382-389

Nagatsu T, Hino M, Fuyamada H, Hayakawa T, Sakibara S,
Nakagawa Y, Takemoto T (1976): New chromogenic substrates for X-Pro dipeptidyl aminopeptidase. Anal Biochem 74:466-476

Reinhold D, Wrenger S, Bank U, Buhling F, Hoffmann T, Neubert K, Kraft M, Frank R, Ansorge S (1996): CD26 mediates the action of HIV-1 Tat protein on DNA synthesis and cytokine production in U937 cells. Immunobiology 195:119-128

Riemann D, Kehlen A, Langner J (1995): Stimulation of the expression and the enzyme activity of aminopeptidase N/CD 13 and dipeptidylpeptidase IV/CD 26 on human renal cell carcinoma cells and renal tubular epithelial cells by T cell-derived cytokines, such as IL- 4 and IL-13. Clin Exp Immunol 100:277-283

Ruiz P, Zacharievich N, Hao L, Viciana AL, Shenkin M (1998): Human thymocyte dipeptidyl peptidase IV (CD26) activity is altered with stage of ontogeny. Clin Immunol Immunopathol 88:156-168

Sakic B, Szechtman H, Braciak T, Richards C, Gauldie J, Denburg JA (1997): Reduced preference for sucrose in autoimmune mice: A possible role of interleukin-6. Brain Res Bull 44:155-165

Scharpé S, De Meester I, Vanhoof G, Hendriks D, Uyttenbroeck W, Ntakarutimana V, Deckx R (1990): Serum DPP IV activity in transplant recipients. Clin Chem 36:984

Schmitz T, Underwood R, Khiroya R, Bachovchin WW, Huber BT (1996): Potentiation of the immune response in HIV-1+ individuals. J Clin Invest 97:1545-1549

Schnittman SM, Vogel S, Baseler M, Lane HC, Davey RT Jr (1994): A phase I study of interferon-alpha $2 \mathrm{~b}$ in combination with interleukin-2 in patients with human immunodeficiency virus infection. J Infect Dis 169:981-989

Scholz W, Mentlein R, Heymann E, Feller AC, Ulmer AJ, Flad HD (1985): Interleukin 2 production by human $T$ lymphocytes identified by antibodies to dipeptidyl peptidase IV. Cell Immunol 93:199-211

Schon E, Demuth H-U, Eichmann E, Horst H-J, Korner I-J, Kopp J, Mattern T, Neubert K, Noll F, Ulmer AJ, Barth A, Ansorge S (1989): Dipeptidyl peptidase IV in human $\mathrm{T}$ lymphocytes. Impaired induction of interleukin 2 and gamma interferon due to specific inhibition of dipeptidyl peptidase IV. Scand J Immunol 29:127-132

Spath-Schwalbe E, Hansen K, Schmidt F, Schrezenmeier H, Marshall L, Burger K, Fehm HL, Born J (1998): Acute effects of recombinant human interleukin-6 on endocrine and central nervous sleep functions in healthy men. J Clin Endocrinol Metab 83:1573-1579

Tanaka T, Duke-Cohan JS, Kameoka J, Yaron A, Lee I, Schlossman SF, Morimoto C (1994): Enhancement of antigeninduced T-cell proliferation by soluble CD26/dipeptidyl peptidase IV. Proc Natl Acad Sci U S A 91:30823086

Taylor JL, Grossberg SE (1998): The effects of interferonalpha on the production and action of other cytokines. Semin Oncol 25(Suppl 1):23-29

Uematsu T, Urade M, Yamaoka M (1998): Decreased expression and release of dipeptidyl peptidase IV (CD26) in cultured peripheral blood T lymphocytes of oral cancer patients. J Oral Pathol Med 27:106-110

Valentine AD, Meyers CA, Kling MA, Richelson E, Hauser P 
(1998): Mood and cognitive side effects of interferonalpha therapy. Semin Oncol 25(Suppl 1):39-47

Van Gool AR, Kruit WHJ, Cornelissen JJ, Berk L, Eggermont AMM, Bannink M (1999): Management of psychiatric adverse events with immunotherapy with interferonalpha. Acta Neuropsychiatrica 11:120-124

Van Hoof G, De Meester I, van Sande M, Scharpé S, Yaron A (1992): Distribution of proline-specific aminopeptidases in human tissues and body fluids. Eur J Clin Chem Clin Biochem 30:333-338

Van Hoof G, Goossens F, De Meester I, Hendriks D, Scharpé $S$ (1995): Proline motifs in peptides and their biological processing. FASEB J 9:736-744

Walker LG, Walker MB, Heys SD, Lolley J, Wesnes K, Eremin O (1997): The psychological and psychiatric effects of rIL-2 therapy: a controlled clinical trial. Psychooncology 6:290-301

Yamabe T, Takakura K, Sugie K, Kitaoka Y, Takeda S, Okubo Y, Teshigawara K, Yodoi J, Hori T (1997): Induction of the 2B9 antigen/dipeptidyl peptidase IV/CD26 on human natural killer cells by IL-2, IL-12 or IL-15. Immunology 91:151-158

Yirmiya R (1996): Endotoxin produces a depressive-like episode in rats. Brain Res 711:163-174

Yirmiya R (1997): Behavioral and psychological effect of immune activation: Implications for depression due a general medical condition. Curr Opin Psychiatry 10:470-476

Zukowska-Grojec Z (1997): Neuropeptide Y: Implications in vascular remodeling and novel therapeutics. Drugs News Perspect 10:587-595 